\title{
How progressive, cosmopolitan and social justice-oriented Islam can help overcome sectarianism
}

Edition 4, 2020

Dr Adis Duderija

DOI: 10.37839/MAR2652-550X4.22

Given the increase in Muslim sectarianism over the last decade or so, especially in the Middle East, one would be forgiven for asking whether the idea of Muslims transcending the historical and religious Sunni-Shi'i divides today would ever be possible (even if one is of the view that it is highly desirable).

The numerous recent events of 'sectarian' or religiously-inspired/justified violence and ongoing repression of many Muslim communities by other Muslims (both within and across sectarian divides in many parts of the Muslim majority world), which have resulted in many lost lives, justify scepticism and lack of optimism in this respect.

However, this rather grim picture ought not deter us from efforts to make the situation better, as problematic as it is. Put differently, the alternative of upholding the status quo is for many Muslims today no longer acceptable on both moral and religious/theological grounds.

Part of the solution is that the intellectual and the lived reality-based arguments for transcending Muslim sectarianism are already in place in the form of what I refer to as the theory of progressive Islam. 


\section{Failures of intra-Muslim ecumenicalism}

The increased ecumenical spirit among various religious traditions (inter-religious) and recognition of irreducible religious pluralism has come a long way recently, at least in theory.

I say this as someone who has been active in inter-faith dialogue (predominantly between the Abrahamic religions) for over 20 years at the grassroots level as well as someone who has an academic interest in the topic. However, the ecumenical spirit at intra-Muslim level has not kept pace with these developments; and with a few exceptions such as the Aman Message (2006) there are hardly any formal institutional efforts that have this aim.

Many socio-political and economic challenges that contribute to sectarianism in the Muslim World are, at least in part rooted in failures of Muslims to think about Islam and the Islamic intellectual tradition in new ways-ways that have the potential to transcend the historical (religio-doctrinal) divides and associated animosities that have existed between Sunnis and Shi'is since the very inception of Islam. There is a great need for Muslims to develop alternative approaches to conceptualising Islam that have the capacity to dislodge the dominant sectarian narratives that have historically led to, and produced, the current Sunni-Shi'i divides. This is where the theory and practice of progressive Islam/progressive Muslim thought comes into the picture.

\section{Progressive Muslim thought is uniquely positioned to overcome these divides}

The theory of progressive Islam in my work draws upon both Sunni (e.g. Khaled Abou El Fadl, Abdulla Saeed, Kecia Ali, Hassan Hanafi, Sadiyya Shaikh, Ebrahim Moosa, Muhammad Al-Jabiri ) and Shi'i scholars (e.g. Z.Mir-Hosseini, A.Sachedina, M.Kadivar, Y. Eshkevari, A.K.Soroush) and conceptualises and approaches the 
Islamic intellectual and cultural heritage (turath) in ways that at least place into the periphery, if not entirely overcome, the religio-doctrinal factors that have led to the formation of Sunni and Shi'i orthodoxies as we know them today.

It is crucial to draw attention to the fact that none of the "pillars' of progressive Islam are tied to the issues and doctrines on which traditional divides between Sunnis and Shi'is rest, namely that of the nature and location of religious authority, the views on the (collective) probity of Prophet Muhammad's Companions and the subsequent political theologies (e.g. imamate and caliphate) that have developed in both their Sunni and Shi'i versions. Furthermore, none of the specifically Sunni and Shi'i doctrines and beliefs mentioned above that are constitutive of and fundamental to each of these traditions within Islam are normative from the perspective of the theory of progressive Islam.

I define mainstream Sunni and Shi'i orthodoxies as they have been defined in the abovementioned Amman Message, namely as forms of Islam which "specifically recognised the validity of all 8 Mathhabs (legal schools) of Sunni, Shi'a and Ibadhi Islam; of traditional Islamic Theology (Ash'arism); of Islamic Mysticism (Sufism), and of true Salafi thought, and came to a precise definition of who is a Muslim." These orthodoxies were laid around the fifth century of the Islamic calendar and continue to this day.

\section{The 'Pillars' of progressive Islam and Islamic sectarianism}

Progressive Islam does not view any of the doctrines and beliefs associated with specific Sunni and Shi'i doctrines as normative, but rather as purely historical. Moreover, the delineating features of progressive Islam in relation to its own definition of itself go beyond the parameters within which both Sunni and Shi'i orthodoxies function epistemologically, hermeneutically and methodologically. Therefore, progressive Islam does not only transcend the limits of Sunni/Shi'i 
orthodoxies in this sense, but it does so without compromising on any of its own fundamental premises/pillars.

\section{Creative, critical and innovative thought based on epistemological openness and methodological fluidity}

This aspect of the theory of progressive Islam is that its exponents do not subscribe to tradition versus modernity, secularism versus religion, or to simplistic generalisations such as modernity equals Western or Judeo-Christian intellectual/civilisational traditions. Therefore, the theoretical architects of progressive Islam are engaged in permanent dialogue with the progressive agendas of other cultures, drawing inspiration from movements such as liberation theology, feminism, and secular humanism.

Importantly, this aspect of progressive Muslim thought enables it to escape mainstream Sunni and Shi'i orthodoxies' interpretations of the sacred past which are constantly being imposed on their contemporary respective believers as nonnegotiable elements of what it means to be a Sunni or a Shi'i. Progressive Muslim thought does not a priori privilege the 'sacred past' in any of these ways, or at all. Moreover, it is radically open to new ideas and re-conceptualisations of the inherited intellectual and cultural heritage (turath) that they can creatively and seemingly integrate into it and thereby creatively yet authentically transform.

\section{Historicist and contextualist approaches to Islamic theology and doctrines}

Progressive Muslim scholars seek to rediscover and build further on historicist and contextualist approaches to Islamic theology as they pertain to the concept of revelation (wahy/tanzil), scriptural reasoning and its methodology (manhaj) and subsequent development of various forms of Islamic theologies, doctrines and 
sectarian soteriologies. All of these are viewed as by-products of historical processes that are continually re-appropriated by various stakeholders and actors both religious and political. Hence, all these aspects of Islamic belief, especially those that are associated with sectarian soteriologies of Sunni and Shi'i orthodoxies are not considered as 'final', but are subject to revision and critique.

Moreover, progressive Muslim theology has many affinities with process theology associated with scholars such as C.H. Hartshorne, J. Cobb and D.R. Griffin, and is a form of Islamic process theology that moves away from classical theistic view of God and God's relationship with the cosmos and the entire creation. In this sense, Islamic process theology is grounded in theories of revelation and religious experience emphasised by Islamic scholars such as Ibn al 'Arabi, M. Iqbal, Nasir Abu Zayd and A.K. Soroush who emphasise the ideas of process and centrality of religious experience as contingent and dynamic.

\section{A human rights-based approach to Islamic tradition}

As noted previously, both Sunni and Shi'i contemporary orthodoxies in terms of their approach to what constitutes valid knowledge and how to arrive at it are premodern, as are their respective approaches concerning the concept of turath, and their theological worldviews pertaining to the question of the nature of God and God's relationship with the Universe and its creation. Being epistemologically premodern has caused a variety of tensions between these orthodoxies and contemporary human rights schemes including in the area of how human dignity and human rights have been conceptualised.

Both Sunni and Shi'i orthodoxies, in relation to their view of the human being, contain a set of ethical, moral and legal rights and responsibilities that differentiate individuals on the basis of their religious belonging (in addition to gender and social class), privileging those that belong to their version of Islam. As such, as argued by scholars such as Sachedina and An 'Naim, they are incompatible with the paradigms 
of modern human rights schemes.

Progressive Muslim thought, on the other hand, in terms of how it approaches the turath is epistemologically (post)-modern and is based on what Sayla Benhabib terms a weak form of post-modernism. In tune with their historicist and contextualist approaches explained above, progressive Muslim scholars, such as Sachedina and An Na'im, approach the issue of compatibility or the relationship between modern human rights discourse and the Islamic tradition by placing both in an historical perspective. This historicist methodology is partly based on a particular conceptualisation of divine ontology whose central tenets are justice and mercy. These values are considered to be sources of universal moral values that are to be extended to and applicable equally to all of humanity regardless of their religion or gender. This argument, in turn, is underpinned by the premise to which progressive Muslim thought subscribes that each human being is considered a unique creation of God having equal dignity, moral worth, and moral agency irrespective of their religious belonging. Hence, each individual and the communities that are comprised of these individuals, including the political, is entitled to enjoy the same inalienable rights. Based on this approach to human rights, progressive Muslim scholars are able to provide the preliminary theoretical foundations for the process of weaving the ethos and the culture of modern human rights discourse into the theological, social and cultural fabric of Muslim-majority societies and thereby transcend the limits of Sunni and Shi'i orthodoxies in this respect, including in the area of women and minority rights.

\section{Islamic Liberation Theology}

For progressive Muslim theologians such as Hassan Hanafi, Ashgar Ali, Farid Esack and Shabbir Akhtar, the concept of revelation is not a primarily theocentric but anthropocentric concept which brings humanity rather than God into the full historical limelight as a subject of study. Furthermore, the so-called five pillars of Islam are considered as religious in their form but political in nature as their content implies free will, freedom to act, responsibility for one's actions and hence the need 
to establish justice and fight injustice. Moreover, the concept of tawhid (usually understood as a theological concept describing 'Divine Unity' as a central tenet of Islamic theology) is considered to be an action-oriented belief system which affirms emancipatory and liberatory practices of the entire humankind and resists oppression, tyranny and injustice regardless of their origin. Progressive Islamic theology, unlike Sunni and, to a lesser extent, Shi'i orthodoxies, prioritises orthopraxis over orthodoxy. In other words, the human and the human condition are central to this type of theology and not a commitment to a rigid set of beliefs and doctrines.

\section{Affirmation of religious pluralism}

Finally, progressive Muslim theology embraces and even thrives on pluralism, diversity, and what is fundamental to all of it, uncertainty. Both mainstream Sunni and Shi'i orthodoxies primarily confine salvation to Muslims (in a reified sense of the term) only.[1] Progressive Muslim scholars such as A.K. Soroush and Farid Esack, on the other hand, theorise and affirm the normative validity of religious pluralism and pluralistic soteriology, on a number of levels. For example, they recognise pluralism at the epistemological level and highlight the difference between 'religion' as an abstract concept and that of religious knowledge as a tangible, messy, historical one. Furthermore, they acknowledge the inescapable pluralism at the level of understanding religious texts (hermeneutics/scriptural reasoning). Finally, progressive Muslim scholars recognise pluralism at the level of religious experiences viewed as contingent and dynamic.

This affirmation of the idea that multiple religious traditions are capable of providing guidance that lead to salvation performs an important function in overall progressive Muslim thought. For instance, this affirmation forms the basis of how progressive Muslim thought conceptualises the idea of human moral responsibility to be just and humble. Religious and salvific pluralism are also viewed as essential preconditions, philosophically speaking, for understanding true meaning of the human condition ontologically that go well beyond the parameters of Sunni and Shi'i orthodoxies that 
are premised on various versions of the 'superiority of a believer over a non-believer' logic.

\section{Building a critical mass}

Beyond theory, I also believe that there is a critical mass of well-informed Muslims, for whom the historical processes that have led to what today is known as Sunni and Shi'i Islam are not fundamental to how they view or relate to themselves as Muslims.

Instead, their sense of Muslimness is underpinned by the kind of approaches to the faith I have outlined that characterise progressive Islam which is less about (political) theology and more about developing a cosmopolitan, social justiceoriented Islam that has a strong ecumenical spirit, not just within the boundaries of reified Islam but across religious difference.

It is my firm conviction that validating and supporting such an approach to Islam is sorely needed today for a host of reasons for both Muslims and non-Muslims alike that includes but goes well beyond the issue of Muslim sectarianism.

[1] Some argued that eventually avoidance of eternal damnation could be extended to non-Muslims but only as result of God's all-encompassing grace and mercy. However, the implication in this view is that these non-Muslims clearly subscribed to false doctrinal and theological views of God by not following 'orthodox' Islam.

Image credit: NaruFoto/Shutterstock 